\title{
Changes in the Nutrient Content of Agricultural Soil on Conversion to Organic Farming in Relation to Farm-Level Nutrient Balances and Soil Contents of Clay and Organic Matter
}

\author{
Løes, A.-K. and Ogaard, A. F. (Norwegian Centre for Ecological \\ Agriculture, NO-6630 Tingvoll, and Department of Soil and Water \\ Sciences, Agricultural University of Norway, Box 5028, NO-1432 Ås, \\ Norway). Changes in the nutrient content of agricultural soil on \\ conversion to organic farming in relation to farm-level nutrient balances \\ and soil contents of clay and organic matter. Accepted February 2, \\ 1998. Acta Agric. Scand., Sect. B, Soil and Plant Sci. 47: 201-214, \\ 1997. (C) 1997 Scandinavian University Press.
}

Agricultural soil on 12 farms converting to organic farming was sampled in 1989 and 1995 at the same sample points. Concentrations of plant-available (-AL) $\mathrm{P}, \mathrm{K}, \mathrm{Ca}$ and $\mathrm{Mg}, \mathrm{HNO}_{3}$-soluble $\mathrm{K}$, total- $\mathrm{N}$, total- $\mathrm{C}$ and $\mathrm{pH}$ were measured in two layers. The average $\mathrm{K}-\mathrm{AL}$ concentration and $\mathrm{pH}$ were reduced in both layers. The average P-AL concentration was reduced in the topsoil. K-AL and P-AL increased in samples with low concentrations and decreased in samples with high and very high concentrations in $1989 . \mathrm{K}_{\mathrm{HNO}}$ increased in the topsoil and total- $\mathrm{N}$ increased in the subsoil. Total- $\mathrm{N}$ and total- $\mathrm{C}$ increased in top- and subsoil with a low organic matter content. The net import of $\mathrm{P}$, calculated by farm-level nutrient balances, was negatively correlated to the change in $\mathrm{kg} \mathrm{P}-\mathrm{AL} \mathrm{ha}{ }^{-1}$ in the topsoil. No such correlation was found for $\mathrm{K}$.

\author{
Anne-Kristin Loes ${ }^{1, *}$ and \\ Anne Falk Ogaard ${ }^{2}$ \\ ${ }^{1}$ Norwegian Centre for Ecological \\ Agriculture, NO-6630 Tingvoll, and \\ ${ }^{2}$ Department of Soil and Water \\ Sciences, Agricultural University of \\ Norway, Box 5028, NO-1432 Ås, \\ Norway
}

\section{Introduction}

Organic agriculture, in Scandinavia called ecological agriculture, is a production system the purpose of which is to produce food for human consumption from the natural resources on the farm, with techniques that respect natural ecological balance and make it possible to avoid products and methods that are contrary to its principle aims. Products and methods avoided in this farming system are synthetic

* Corresponding author fertilizers, pesticides, industrial livestock management, unnatural forcing of plant and animal growth, etc. (IFOAM, 1994). In 1996, there were 946 Norwegian farms which either practised organic farming, or which were in the process of conversion (Debio, 1997a). The standards for organic agriculture set firm restrictions on purchased nutrients. Inorganic nitrogen fertilizers are not allowed; other fertilizers only with dispensation. The amount of purchased conventional fodder in Norway is restricted to $20 \%$ of the total fodder consumption on an energy basis on the farm. Certified organic fodder can be purchased up to 


\section{A.-K. Loes and A. F. Ogaard}

a limit of $33 \%$ of the total feed consumption. but is usually not available (Debio, 1997b).

Farm-level nutrient budgets usually show less net import (import minus export) on organic than on conventional farms with comparable productions. Organic dairy farms in Norway had an average net import of $12 \mathrm{~kg}$ nitrogen $(\mathrm{N}), 2 \mathrm{~kg}$ phosphorus (P) and $10 \mathrm{~kg}$ potassium $(\mathrm{K}) \mathrm{ha}^{-1} \mathrm{yr}^{1}$, whereas dairy farms which recently had started conversion had a net import of $69 \mathrm{~kg} \mathrm{~N}, 10 \mathrm{~kg} \mathrm{P}$ and $26 \mathrm{~kg} \mathrm{~K} \mathrm{ha}^{-1}$ $\mathrm{yr}^{-1}$ (Kerner \& Solberg, 1993). Net import on Danish ecological dairy farms varied from 10 to $-31 \mathrm{~kg}$ $\mathrm{N}, 8$ to $-1 \mathrm{~kg} \mathrm{P}$ and 3 to $-18 \mathrm{~kg} \mathrm{~K} \mathrm{ha}^{-1} \mathrm{yr}^{-1}$ (Askegaard \& Mikkelsen, 1995). An interesting question is how reduced net import of nutrients to the farm during and after conversion influences the concentrations of plant-available nutrients in the soil.

On organic plots with positive nutrient balances for $\mathrm{P}$ and negative balances for $\mathrm{K}$ in a long-term field experiment in Järna, Sweden, the concentration of plant-available $\mathrm{P}$ (ammonium acetate lactate soluble $\mathrm{P}, \mathrm{P}-\mathrm{AL}$ ) increased and the plant-available $\mathrm{K}$ concentration did not vary greatly over time. The soil was a silty loam. On average for three organic plots, the P-AL concentration increased from 3.4 to $9.8 \mathrm{mg} \mathrm{P}$ per $100 \mathrm{~g}$ soil from 1958 to 1985 . The K-AL concentration was 14.5 and $12.7 \mathrm{mg} \mathrm{K}$ per $100 \mathrm{~g}$ soil in 1958 and 1985, respectively (Pettersson et al., 1992). The average $P$ balance was +15 and the $\mathrm{K}$ balance -38 $\mathrm{kg} \mathrm{ha} \mathrm{yr}^{-1}$ (recalculated from Pettersson et al. 1992).

The average concentrations of plant-available nutrients and $\mathrm{pH}$ were reduced after 11 years of negative nutrient-balances in a Norwegian long-term investigation on an organic dairy farming system. The soil was silty sand with a low nutrient content, located in northwestern Norway (Hansen, 1997). The $\mathrm{K}_{\mathrm{HNO3}}$ concentration was reduced from 38 to $30 \mathrm{mg}$ $\mathrm{K}, \mathrm{P}-\mathrm{AL}$ from 10 to $7 \mathrm{mg} \mathrm{P}, \mathrm{K}-\mathrm{AL}$ from 5 to $4 \mathrm{mg}$ $\mathrm{K}$ and $\mathrm{Mg}-\mathrm{AL}$ from 4 to $2 \mathrm{mg} \mathrm{Mg}$ per $100 \mathrm{~g}$ dry soil from 1985 to 1995 , and $\mathrm{pH}\left(\mathrm{H}_{2} \mathrm{O}\right)$ was reduced from 6 to 5.6. The average nutrient balances (manure minus harvest) on field level were $-35 \mathrm{~kg} \mathrm{~N},-20 \mathrm{~kg} \mathrm{~K}$, $-8 \mathrm{~kg} \mathrm{P},+1 \mathrm{~kg} \mathrm{Mg}$ and $-15 \mathrm{~kg} \mathrm{Ca} \mathrm{ha}^{-1} \mathrm{yr}^{-1}$.

The average concentrations of plant-available $P$ and $\mathrm{K}$ were reduced in soil on organic plots in a long-term experiment in Switzerland (DOK-trial) with negative nutrient balances. Plant-available $P$ and $\mathrm{K}$ concentrations were extracted with $0.02 \mathrm{M}$ calcium-lactate and $0.02 \mathrm{M} \mathrm{HCl}$ (P-DL, K-DL). P-DL was reduced from 2.6 to $1.9 \mathrm{mg} \mathrm{P}$ and $\mathrm{K}$-DL from 6.1 to $5.2 \mathrm{mg} \mathrm{K}$ per $100 \mathrm{~g}$ soil from 1980 to 1991 . The average nutrient balance was $-3.5 \mathrm{~kg} \mathrm{P}$ and $-53 \mathrm{~kg}$ $\mathrm{K} \mathrm{ha}^{-1} \mathrm{yr}^{-1}$ (Alföldi et al., 1993). Organic plots with even more negative nutrient balances had greater reductions in the P-DL and K-DL concentrations.
A Danish whole farm case study project investigated the concentrations of plant-available $P$ and $K$ in the soil on 13 organic dairy farms in 1988 and 1992 (Kristensen \& Halberg, 1995). Plant-available K was extracted with $0.5 \mathrm{M}$ ammoniumacetate (Kt) and plant-available $\mathrm{P}$ was extracted with $0.5 \mathrm{M}$ sodiumbicarbonate (Pt) (Olsen et al., 1954). Four farms on clay soil which had been organically farmed for many years had low P-concentrations in the soil, with $47-$ $66 \%$ of the soil samples containing $<2 \mathrm{mg}$ plantavailable $\mathrm{P}$ per $100 \mathrm{~g}$ dry soil. Despite the low concentrations of plant-available $P$ in the soil, acceptable grain yields were taken. Symptoms of $\mathrm{N}$ and $\mathrm{P}$ deficiency were observed early in the growing season, but diminished during the summer. On average, farms converted in 1982-89 had higher concentrations of plant-available $\mathrm{P}$ in the soil. The average $\mathrm{P}$-concentration on all farms was $3.2 \mathrm{mg} \mathrm{P}$ per $100 \mathrm{~g}$ soil; only $18 \%$ of the samples had concentrations $<2$ $\mathrm{mg}$. The average $\mathrm{K}$-concentration was $11 \mathrm{mg} \mathrm{K}$ per $100 \mathrm{~g}$ soil, and was lower in sand than in clay soil. Average farm-level nutrient balances were positive, 8 $\mathrm{kg} \mathrm{P}$ and $15 \mathrm{~kg} \mathrm{~K} \mathrm{ha}^{-1} \mathrm{yr}^{-1}$.

The objective of the present soil investigation was to determine whether there are some indications of changes in the content of plant-available nutrients, organic matter and $\mathrm{pH}$ in the soil on a selection of Norwegian farms during conversion to organic farming. Agricultural soil on 12 organic and converting farms was sampled in 1989 and 1995. The relationships between changes in $\mathrm{kg}$ plant-available $\mathrm{P}$ and $\mathrm{K}$ per hectare in the upper soil layer and the net import of $\mathrm{P}$ and $\mathrm{K}$ on farm level were investigated. The study was part of a whole farm case study project (198996) carried out at the Norwegian Centre for Ecological Agriculture.

\section{Material and methods}

\section{Presentation of the farms}

The twelve investigated farms were located in different regions of the country, as shown in Fig. 1. Milk production was the main income on 10 out of 12 farms. The altitude, annual precipitation, year of conversion, main production, mineral soil type according to Sveistrup \& Njøs (1984); average content of corrected clay (see below), organic matter, plantavailable and acid-soluble $K$ and plant-available $P$ in the topsoil in 1989 for each farm are all recorded in Table 1.

The farms were grouped according to the level of net import (=import minus export) of $\mathrm{P}$ and $\mathrm{K}$, which was calculated from farm accounts and summarized for the six years" investigation period (198994). Import is amounts of $P$ and $K$ in purchased 
Changes in agricultural soil on conversion to organic farming

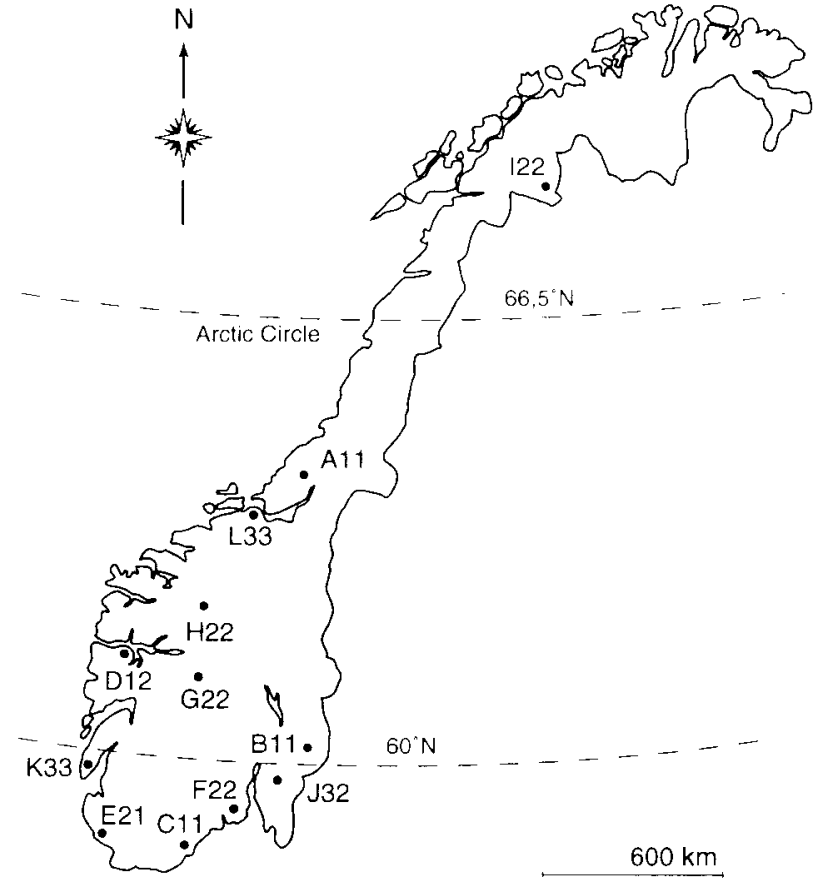

Fig. 1. Location of the 12 farms participating in the investigation.

fodder, animals, seed, etc., and export is amounts of $\mathrm{P}$ and $\mathrm{K}$ in sold products as milk, meat, grains, etc. Amounts of purchased and sold products were multiplied by contents of $\mathrm{P}$ and $\mathrm{K}$ as published in Ebbesvik (1997). Nutrient imports from rainfall and dry deposits as well as nutrient exports caused by surface runoff or other liquid losses were not included.

Based on the calculations of net $\mathrm{P}$ and $\mathrm{K}$ import, the investigated farms were grouped into three levels, expressed as $\mathrm{kg} \mathrm{P}$ and $\mathrm{K}$ per hectare, sum of six years.

Low level, $\mathrm{I}=$ for $\mathrm{P}:-4-11$, for $\mathrm{K}: 45-53 \mathrm{~kg} \mathrm{ha}^{-1}$ Medium level, 2 = for P: $27-49$, for $\mathrm{K}: 83-200 \mathrm{~kg}$ ha I

High level, $3=$ for $P: 62-158$, for $\mathrm{K}: 325-442 \mathrm{~kg}$ ha $^{-1}$

A letter and two numbers, showing the level of net imports of $\mathbf{P}$ and $K$, respectively represent each farm. The farms with a low net import of $\mathrm{P}$ and $/$ or $\mathrm{K}$ were converted before, or early in the project period. The farms with medium net $\mathrm{P}$ and $\mathrm{K}$ import completed conversion later in the project period, and the farms with high net $\mathrm{P}$ and $\mathrm{K}$ import are still in the process of conversion.

In Norway, the nutrient status of agricultural soil is classified according to the concentrations of nutrients shown in Table 2 . The investigated farms had medium to very high concentrations of plant-available $\mathrm{P}$, low to high concentrations of plant-available $\mathrm{K}$ and a low to very high concentrations of acid-soluble $K$ in the topsoil $(0-20 \mathrm{~cm})$ in 1989 . In general, the concentrations of nutrients in the soil were medium to high.

Table 1. General information on each farm: FARM = Number according to level of net import of $P$ and $K$ (see presentation of the farms and Fig. 2), ALT=altitude (m above sea level); RAIN = annual precipitation (mm); CON.YEAR = conversion year, defined as the first year all productions were, or are planned to be, certified as organic; MAIN PROD. = main production; MINERAL SOIL = main soil type according to Sveistrup \& Njos (1984); CLAY $\%=$ average and ( $\min -\max$ ) content of corrected clay in the topsoil $(0-20 \mathrm{~cm})$; ORG.M \% = average and ( $\min -\max$ ) content of organic matter in the topsoil in 1989; K-AL, $K_{\mathrm{HNO}}, \mathrm{P}-\mathrm{AL}=$ average and (min-max) concentrations of plant-available $K$, acid-soluble $K$ and plant-available $P$ in the topsoil in 1989 , as $\mathrm{mg} \mathrm{K}$ or $P$ per $100 \mathrm{~g}$ dry soil

\begin{tabular}{|c|c|c|c|c|c|c|c|c|c|c|}
\hline FARM & $\begin{array}{l}\text { ALT. } \\
\mathrm{m}\end{array}$ & $\begin{array}{l}\text { RAIN } \\
\mathrm{mm}\end{array}$ & $\begin{array}{l}\text { CON. } \\
\text { YEAR }\end{array}$ & $\begin{array}{l}\text { MAIN } \\
\text { PROD. }\end{array}$ & $\begin{array}{l}\text { MINERAL } \\
\text { SOIL }\end{array}$ & $\begin{array}{l}\text { CLAY } \\
\%\end{array}$ & $\begin{array}{l}\text { ORG.M. } \\
\%\end{array}$ & $\mathrm{~K}-\mathrm{AL}$ & $\mathrm{K}_{\mathrm{HNO}}$ & P-AL \\
\hline A11 & 60 & 1290 & 1992 & Sheep & Clay & $15(0-23)$ & $8(3-42)$ & $14(3-33)$ & $144(83-194)$ & $11(3-23)$ \\
\hline B11 & 170 & 753 & 1986 & Milk & Sand, silt, clay & $8(2-12)$ & $5(4-9)$ & $7(3-21)$ & $32(20-48)$ & $6(2-14)$ \\
\hline C11 & 50 & 1294 & 1991 & Milk & Sand, clay & $11(5-16)$ & $12(5-66)$ & $17(5-29)$ & $52(29-89)$ & $14(6-24)$ \\
\hline D12 & 25 & 1094 & 1989 & Milk & Sand, silt & $6(2-12)$ & $5(2-9)$ & $15(4-33)$ & $149(101-212)$ & $15(3-34)$ \\
\hline E21 & 10 & 1254 & 1996 & Milk & Sand, clay & $7(0-20)$ & $36(5-72)$ & $11(6-30)$ & $36(20-91)$ & $14(5-27)$ \\
\hline F22 & 90 & 1035 & 1994 & Milk & Clay & $24(15-40)$ & $8(3-61)$ & $18(6-36)$ & $90(50-122)$ & $8(4-12)$ \\
\hline $\mathrm{G} 22$ & 660 & 690 & 1994 & Milk & Sand & $1(0-4)$ & $14(5-69)$ & $21(7-59)$ & $72(48-106)$ & $21(2-46)$ \\
\hline $\mathrm{H} 22$ & 490 & 321 & 1997 & Milk & Sand & $4(3-4)$ & $7(4-14)$ & $16(4-109)$ & $131(45-225)$ & $21(3-75)$ \\
\hline 122 & 220 & 282 & 1998 & Milk & Sand, silt & $5(2-7)$ & $4(2-10)$ & $6(1-25)$ & $141(111-265)$ & $9(3-19)$ \\
\hline $\mathrm{J} 32$ & 190 & 816 & 1998 & Grain, beef & Clay & $26(16-33)$ & $4(3-6)$ & $18(9-28)$ & $117(42-172)$ & $6(2-12)$ \\
\hline K33 & 25 & 1630 & 1997 & Milk, sheep & Sand, clay & $5(1-7)$ & $29(11-79)$ & $14(6-31)$ & $22(20-23)$ & $15(3-37)$ \\
\hline L33 & 10 & 1048 & 1999 & Milk, pork & Sand & $4(0-7)$ & $14(4-55)$ & $9(5-21)$ & $30(21-44)$ & $20(4-49)$ \\
\hline
\end{tabular}


Table 2. Classification of the content of plantavailable nutrients and acid-soluble $\mathrm{K}\left(\mathrm{K}_{\mathrm{HNO}}\right)$ in Norwegian agricultural soil. All values in $\mathrm{mg} \mathrm{P}, \mathrm{K}, \mathrm{Mg}$ or Ca per $100 \mathrm{~g}$ dry soil

\begin{tabular}{lcccc}
\hline Class & Low & Medium high & High & Very high \\
\hline P-AL & $0-2$ & $3-6$ & $7-15$ & $>15$ \\
K-AL & $0-6$ & $7-15$ & $16-30$ & $>30$ \\
K $_{\text {HNO3 }}$ & $<30$ & $30-79$ & $80-119$ & $>120$ \\
Mg-AL & $0-2$ & $3-5$ & $6-9$ & $>9$ \\
Ca-AL & $<50$ & $51-100$ & $101-200$ & $>200$ \\
\hline
\end{tabular}

\section{Soil sampling and analysis}

Soil samples were taken twice from cultivated soil; in late autumn 1989 and 1995 (after harvesting). To ensure that the sample points in 1995 were the same as those in 1989, the points were described on detailed maps. From the topsoil layer $(0-20 \mathrm{~cm})$, one composite sample was taken per 0.5 ha, making a total of 310 samples. From the subsoil layer $(20-40$ $\mathrm{cm}$ ), one composite sample was taken per 2 ha, totalling 87 samples. At these 87 points, the topsoil was also sampled. Each composite sample consisted of 10 soil cores, which were taken with an auger at a distance of $0-5.5 \mathrm{~m}$ from the sample point.

All soil samples were analysed for plant-available $\mathrm{P}, \mathrm{K}, \mathrm{Mg}$ and $\mathrm{Ca}, \mathrm{pH}$, Bondorf bulk density, total- $\mathrm{N}$ and total-C. Soil samples from the 87 points where both layers were sampled were analysed for particlesize distribution of mineral material and acid-soluble $\mathrm{K}$ additionally. All analyses were carried out at the Norwegian Agricultural Service Laboratory, Ås. Because some samples were peat soil, the number of samples analysed for particle-size distribution was 83 in the topsoil and 84 in the subsoil. On some sites, extra analyses of acid-soluble $\mathrm{K}$ in the topsoil was required in 1989 and/or 1995, and thus the number of samples varies from 96 to 91 in the presentation of the results.

Plant-available P, K, Mg and Ca were determined by the method of Égner et al. (1960), where the soil was extracted with an ammonium acetate lactate solution $(0.1 \mathrm{M}$ ammonium lactate and $0.4 \mathrm{M}$ acetic acid, $\mathrm{pH} 3.75$ ) in the ratio of soil to solution of $1: 20$ $(\mathrm{w} / \mathrm{v})$. The concentrations of $\mathrm{P}, \mathrm{K}, \mathrm{Mg}$ and $\mathrm{Ca}$ in the extracts were measured with an ICP apparatus. In the text these fractions are abbreviated as P-AL, K-AL, Mg-AL and Ca-AL. Soil pH was measured in a soil-water suspension $(1: 2.5 \mathrm{v} / \mathrm{v})$. The total-C and total- $\mathrm{N}$ concentrations in the soil were determined using a Perkin Elmer 2400 analyser. In this study, total-C was presumed to consist primarily of organic $C$, because of the low likelihood of carbonates in the samples. The soil content of organic matter was calculated as total-C multiplied by 1.724 (Scheffer \& Schachtschabel, 1982). Acid-soluble K was extracted by boiling the soil sample for $10 \mathrm{~min}$ in $1 \mathrm{M} \mathrm{HNO}_{3}$. After filtration the $\mathrm{K}$-concentration in the extract was measured by atomic adsorption. In the text, this fraction is abbreviated as $\mathrm{K}_{\mathrm{H} \text { No33. }}$.

The bulk density was measured in 1995 only, according to the method of Bondorf (1950). The particle-size distribution of the mineral material $<2 \mathrm{~mm}$ was determined by the pipette method (Elonen, 1971). In this study, the amount of clay (particles $<0.002 \mathrm{~mm}$ ) was used as a parameter in a correlation analysis. The clay content determined by the pipette method is a percentage value where the sum of sand, silt and clay (i.e., all particles $<2 \mathrm{~mm}$ ) is 100. Gravel (particles $>2 \mathrm{~mm}$ ) was removed by sieving and organic matter by wet oxidation with $\mathrm{H}_{2} \mathrm{O}_{2}$ before the particle-size distribution was measured. When a sample contained much organic matter and/or gravel, the clay content according to the pipette method deviated considerably from what would be the correct value in natural soil. Hence, the amount of clay in the soil samples according to the pipette method was corrected using the following formula:

$(100-\%$ organic matter $-\%$ gravel $) 100 \times \%$ clay according to the pipette method $=$ corrected $\%$ clay

For most samples, the difference between the clay content according to the pipette method and the corrected clay content was 1 or $2 \%$. In the most extreme case when the soil was very rich in organic matter, the clay content was reduced from $31 \%$ to $7 \%$. The corrected clay content of one soil sample became negative, but was set to $0 \%$.

\section{Nutrient concentrations and reserves}

The content of plant nutrients is presented as concentrations ( $\mathrm{mg} 100 \mathrm{~g}$ dry soil ${ }^{-1}$ ) and reserves ( $\mathrm{kg} \mathrm{ha}{ }^{-1}$ in the topsoil, $0-20 \mathrm{~cm}$ ). Total- $\mathrm{C}$ and total- $\mathrm{N}$ are presented as percentage values. To find the reserves, the concentrations were multiplied by the weight per hectare of the topsoil layer. We assume that the bulk density values were the same in 1989 as in 1995. Plant roots penetrate a certain volume of soil. Hence, the nutrient content in a certain soil volume is a better characterization of the soil's nourishing capacity than the nutrient concentration in a certain weighed amount of soil. But nutrient values measured in $\mathrm{kg}$ $\mathrm{ha}^{-1}$ are based on concentrations, which are measured in soil particles $<2 \mathrm{~mm}$. If the soil contains a large number of particles $>2 \mathrm{~mm}$, these values will become too high compared with realistic field values. In addition, nutrient values measured in $\mathrm{kg} \mathrm{ha}^{-1}$ will be influenced by bias in bulk density measurements. 
Table 3. Overall average concentrations of nutrients, total- $\mathrm{N}$, total- $\mathrm{C}$ and $\mathrm{pH}$ in topsoil $(0-20 \mathrm{~cm})$ and subsoil $(20-40 \mathrm{~cm})$. Values in $\mathrm{mg}$ nutrient per $100 \mathrm{~g}$ dry soil, except for total- $\mathrm{N}$ and total-C $=$ weight $\%$. Diff. $=$ value in 1995 minus value in 1989. $n=$ number of samples

\begin{tabular}{|c|c|c|c|c|c|c|c|c|}
\hline Year & $\mathrm{pH}$ & P-AL & $\mathrm{K}-\mathrm{AL}$ & Ca-AL & $M g-A L$ & $\mathrm{~K}_{\mathrm{NHO3}}$ & Total-N & Total-C \\
\hline \multicolumn{9}{|c|}{ Topsoil: } \\
\hline 1989 & 6.0 & 12.9 & 14.1 & 172 & 16.1 & 89.5 & 0.39 & 6.3 \\
\hline 1995 & 5.9 & 12.4 & 11.7 & 173.2 & 15.6 & 97.5 & 0.41 & 6.3 \\
\hline Diff. & $-0.1^{* * *}$ & $-0.5^{* *}$ & $-2.4^{* * *}$ & $1.2^{\text {ns }}$ & $-0.5^{\mathrm{ns}}$ & $8.0^{* *}$ & $0.02^{*}$ & $0.0^{\text {ns }}$ \\
\hline$n$ & 310 & 310 & 310 & 310 & 310 & 96 & 310 & 310 \\
\hline \multicolumn{9}{|c|}{ Subsoil: } \\
\hline 1989 & 6.0 & 7.0 & 8.6 & 117 & 16.8 & 103.3 & 0.21 & 3.8 \\
\hline 1995 & 5.9 & 6.9 & 7.4 & 117.4 & 14.4 & 106.3 & 0.25 & 4.1 \\
\hline Diff. & $-0.1^{* * *}$ & $-0.1^{n s}$ & $-1.2^{*}$ & $0.4^{\mathrm{ns}}$ & $-2.4^{*}$ & $3.0^{\mathrm{ns}}$ & $0.04 * * *$ & $0.3^{\mathrm{ns}}$ \\
\hline$n$ & 87 & 87 & 87 & 87 & 87 & 87 & 87 & 87 \\
\hline
\end{tabular}

Hence, concentrations were used to study changes over time and reserves $(\mathrm{kg}$ nutrient per hectare topsoil) to study the relationship between these changes and net import. Changes were analysed by paired t-tests, and relationships by correlation analysis. In the tables, the levels of significance are abbreviated ns (not significant) for $P>0.05, *$ for $P<0.05$, ** for $P<0.01$ and $* * *$ for $P<0.001$. To investigate whether the changes in total- $N$ and total- $C$ were dependent on the soil's content of organic matter, the samples were grouped according to the total- $\mathrm{C}$ concentration in 1989. Paired t-tests were carried out in each of six groups defined by Sveistrup (1984): 0-1.7, $1.7-3.5, \quad 3.5-7, \quad 7-11.6, \quad 11.6-23.2$ and $>23.2$ weight $\%$ total-C.

\section{Results}

\section{Average levels and changes of nutrient concentrations, organic matter (total-C) and $\mathrm{pH}$}

The overall average P-AL concentration in the topsoil was classified as high in 1995 as well as in 1989 , but was significantly reduced from 12.9 to $12.4 \mathrm{mg} \mathrm{P}$ per $100 \mathrm{~g}$ dry soil (Table 3 ). The average P-AL concentration in the subsoil was lower than in the topsoil (approx. $7 \mathrm{mg}$ per $100 \mathrm{~g}$ dry soil), and was not significantly changed from 1989 to 1995 . Only one of the 310 topsoil samples in 1989, and four in 1995, had low concentrations of P-AL.

The average $\mathrm{K}-\mathrm{AL}$ concentration was medium high in both layers in 1989 as well as in 1995. K-AL was significantly reduced from 14.1 to $11.7 \mathrm{mg} \mathrm{K}$ per 100 $\mathrm{g}$ dry soil in the topsoil, and from 8.6 to 7.4 in the subsoil (Table 3). In 1989, 69 topsoil samples and 64 in $1995(21 \%)$ had low concentrations of K-AL.
The average $\mathrm{K}_{\mathrm{HVO}}$ concentration was high in both layers in 1989 and 1995, on average highest in the subsoil. The average concentration was significantly increased in the topsoil, from 89.5 to $97.5 \mathrm{mg} \mathrm{K}$ per $100 \mathrm{~g}$ dry soil. No significant change was found in the subsoil (Table 3 ).

The average $\mathrm{Mg}-\mathrm{AL}$ concentration in the topsoil was approximately $16 \mathrm{mg} \mathrm{Mg}$ per $100 \mathrm{~g}$ dry soil (classified as very high), with no significant change from 1989 to 1995. In the subsoil the average Mg-AL concentration was significantly reduced from 16.8 to $14.4 \mathrm{mg}$ per $100 \mathrm{~g}$ dry soil. The average Ca-AL concentration was high in both layers, with no significant changes.

The concentrations of total- $\mathrm{N}$ and total- $\mathrm{C}$ varied considerably between sites, ranging from 0.002 to $2.4 \%$ total- $\mathrm{N}$ and 0.3 to $43.5 \%$ total-C. As shown in Table 1, the organic matter content in the topsoil also varied considerably within farms. Average values of total- $\mathrm{N}$ and total- $\mathrm{C}$ were higher in the topsoil than in the subsoil. The average total-C content was $6.3 \%$ in the topsoil and approximately $4 \%$ in the subsoil, with no significant change from 1989 to 1995 . The average total- $\mathrm{N}$ concentration increased significantly in both layers, from 0.39 to $0.41 \%$ in the topsoil and from 0.21 to $0.25 \%$ in the subsoil. The increase in total- $\mathrm{N}$ in the topsoil can be traced to the fertilizing practice on farm J32, where large amounts of horse manure and some sewage sludge were used to enhance the content of organic matter in the clay soil. When $\mathbf{J} 32$ was excluded the increase in total- $\mathrm{N}$ in the topsoil was no longer significant. The overall increase of total- $\mathrm{N}$ in the topsoil is therefore not discussed any further. The increase in total- $\mathrm{N}$ in the subsoil could, however, not be related to the fertilizing practice on farm $\mathrm{J} 32$. 


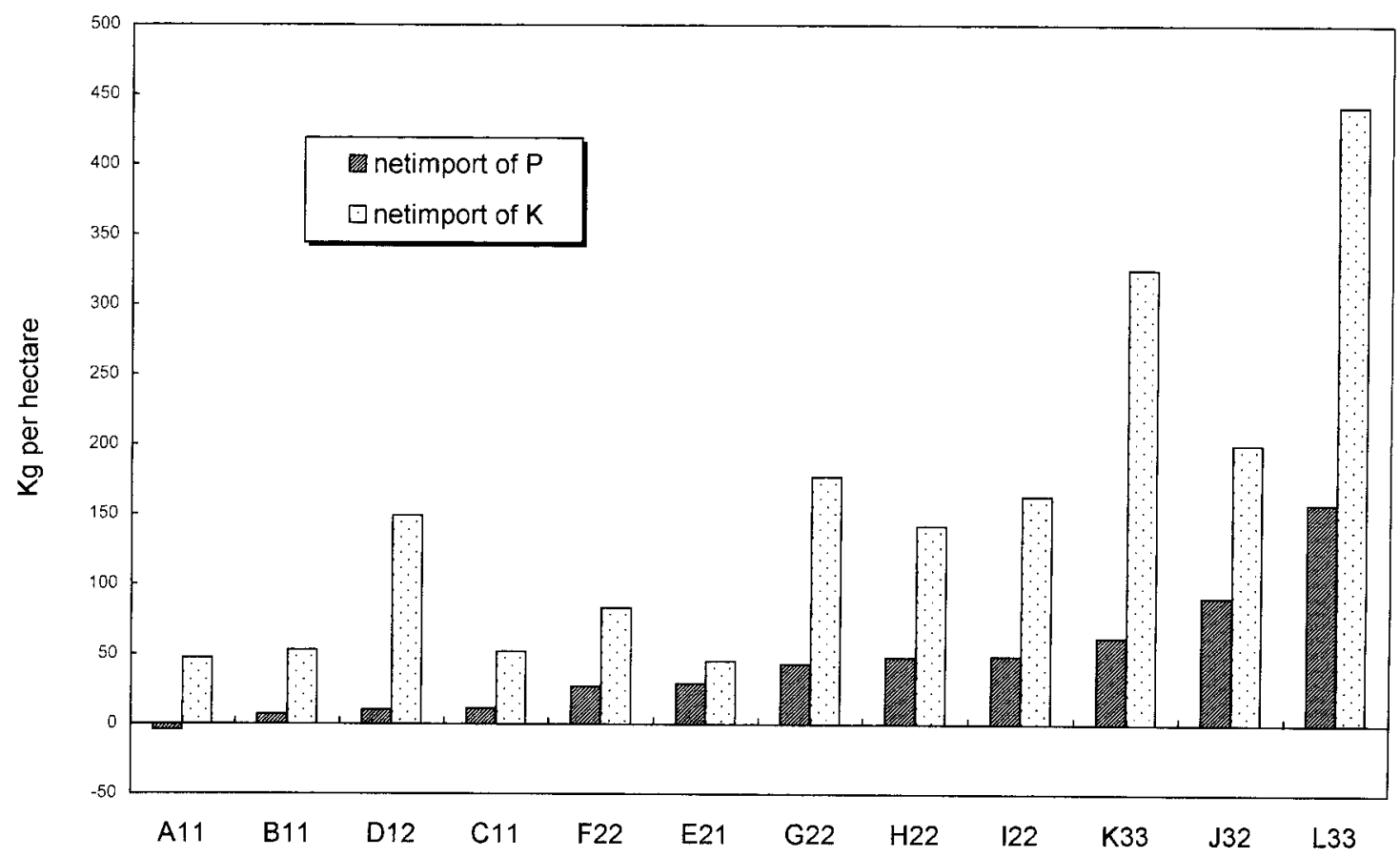

Fig. 2. Net import of $\mathbf{P}$ and $\mathrm{K}$ on the 12 investigated farms (A11-L33), sum of six years (1989-94), kg ha '. The farms are arranged by increasing levels of net import of $\mathrm{P}$.

On average, soil $\mathrm{pH}$ decreased significantly from 6.0 to 5.9 in both layers. Normally, soil pH should be at least $5.5-6.0$ for agricultural production; $18 \%$ of the topsoil and $15 \%$ of the subsoil samples had $\mathrm{pH}$ values below 5.5 in 1995. From 1989 to 1995, six farms had experienced significant reductions in the topsoil $\mathrm{pH}$ and three farms in the subsoil $\mathrm{pH}$.

When the nutrient content was calculated as reserves instead of concentrations, the same significant results were found for the subsoil. In the topsoil, significant reductions of $\mathrm{P}-\mathrm{AL}$ and $\mathrm{K}-\mathrm{AL}$ were still found, but there were no significant changes in $\mathrm{K}_{\mathrm{HNO}}$ and total-N.

\section{Net import of $P$ and $K$ in relation to changes in $P$ and $K$ topsoil concentrations and reserves}

The net import of $\mathrm{P}$ and $\mathrm{K}\left(\mathrm{kg} \mathrm{ha}^{-1}\right.$, sum of six years) varied considerably between the farms, ranging from A11 with $-4 \mathrm{~kg} \mathrm{P}$ and $47 \mathrm{~kg} \mathrm{~K}$ to L33 with 158 $\mathrm{kg} \mathrm{P}$ and $442 \mathrm{~kg} \mathrm{~K}$ (Fig. 2). The calculated values for All are not quite correct because nutrient import from forest and mountain grazing by sheep was not included in the farm-level nutrient budgets. D12 imported large amounts of whey, which contains $0.16 \%$ potassium. J32 imported household wastes for composting and had no export of animal products in the investigated period. L33 purchased fodder for conventional production of pigs for slaughter. For most farms, the net import of both $\mathrm{P}$ and $\mathrm{K}$ was reduced from 1989 to 1994.
Most farms had comparable levels of P-AL and K-AL reserves, but two farms (F22 and J32) had approximately twice as much K-AL as P-AL, whereas L33 had approximately twice as much P-AL as $\mathrm{K}$-AL reserves (Fig. 3). In general, reductions in average $\mathrm{K}-\mathrm{AL}$ reserves were larger than reductions in average $\mathrm{P}-\mathrm{AL}$ reserves.

Significant reductions in the average topsoil P-AL concentration were found on all farms with net import of P classified as low (A11, B11, C11 and D12) and on F22. A significant increase was found on K33. When using reserves $\left(\mathrm{kg} \mathrm{ha}^{-1}\right.$ in the topsoil) instead of concentrations, all farms with low and medium net import of $\mathrm{P}$ had a decrease in the P-AL capital in the topsoil, whereas three farms with a high net import of $P$ had an increase (Fig. 3).

Significant reductions in the average topsoil K-AL concentration were found on A11, C11, F22, G22, H22 and J32. Significant increases were not found on any of the farms. Expressed as reserves, three farms (E21, I22 and L33) increased their topsoil K-AL reserves, but the increases were small compared with the reductions on the other farms. The largest reduction in $\mathrm{K}-\mathrm{AL}$ reserve occurred on $\mathrm{Cl1}$, which had a net import from 1989 to 1994 of only $52 \mathrm{~kg} \mathrm{~K} \mathrm{ha}^{-1}$ $\left(=8.7 \mathrm{~kg} \mathrm{ha}^{-1} \mathrm{yr}^{-1}\right)$. In general, the relationship between net import of $\mathrm{K}$ and reductions/increases in $\mathrm{K}-\mathrm{AL}$ reserves is not clear.

Significant reductions in the average topsoil $\mathrm{K}_{\mathrm{HNO}}$ concentration were not found on any farm, whereas a significant increase was found on I22. The average 


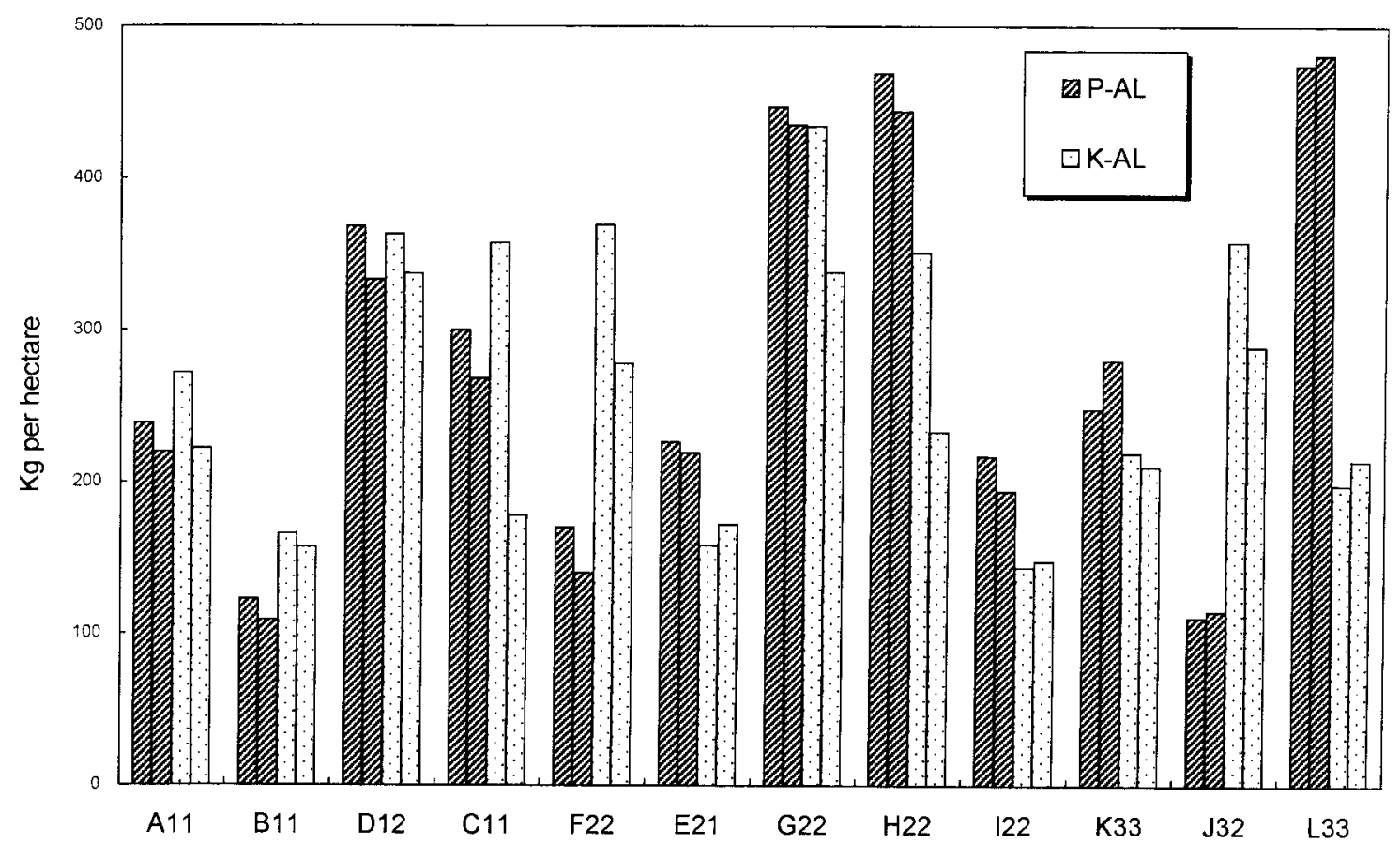

Fig. 3. P-AL and K-AL reserves in the topsoil $(0.20 \mathrm{~cm})$ on the 12 investigated farms (A11 - L33) in 1989 compared to 1995, $\mathrm{kg}^{-1}$ Left part of double column $=1989$, right part $=1995$.

$\mathrm{K}_{\mathrm{HNO3}}$ reserves were in general much larger than the $\mathrm{K}-\mathrm{AL}$ reserves (Fig. 4), except at $\mathrm{K} 33$. Increase in the average $K_{\mathrm{HNO}}$ reserves was found on eight farms, and reduction on four farms. The reductions were small compared with the increases. The largest increases (11 to $40 \mathrm{~kg} \mathrm{~K} \mathrm{ha}^{-1}$ ) in $\mathrm{K}_{\mathrm{HNO3}}$ reserves occurred on A11, F22, I22 and L22. On I22 and L22 the average $\mathrm{K}-\mathrm{AL}$ reserves increased as well, whereas the K-AL reserves decreased on $A 11$ and F22. On $\mathrm{C} 11, \mathrm{H} 22$ and $\mathrm{K} 33$ there were reductions in the average $\mathrm{K}_{\mathrm{HNO}}$ as well as $\mathrm{K}-\mathrm{AL}$ reserves, whereas E21 experienced reduction in $\mathrm{K}_{\mathrm{HNO}}$ and increase in $\mathrm{K}$-AL reserves.

To investigate whether the changes in topsoil $\mathrm{P}-\mathrm{AL}$ and K-AL reserves from 1989 to 1995 were related to the farms' net import of $\mathrm{P}$ and $\mathrm{K}$ in this period, a correlation analysis was carried out. The change in the average topsoil $\mathrm{K}_{\mathrm{HNO}}$ concentration was not significant when expressed as $\mathrm{kg} \mathrm{ha}^{-1}$, and therefore the changes in $\mathrm{K}_{\mathrm{HNO}}$ reserves were not included in the correlation analysis. A significant negative correlation was found between the net import of $P$ and the reduction in the average topsoil $\mathrm{P}-\mathrm{AL}$ reserves on each farm $\left(r=-0.60^{*}\right)$. The level of the average P-AL reserve was not correlated to the net import of $P$ in 1989, nor in 1995 either. Neither the reduction in the average $\mathrm{K}-\mathrm{AL}$ reserve nor the levels of the K-AL reserve in 1989 or 1995 were correlated to the net import of $\mathrm{K}$.

\section{Relationship between changes in nutrient concentrations, organic matter and $\mathrm{pH}$ and some soil parameters}

In order to study the relationship between the significant changes in plant nutrient concentrations and $\mathrm{pH}$ and some soil parameters, a correlation analysis was carried out. The soil parameters were corrected clay content, content of total-C in 1989, pH in 1989 and the 1989 concentrations of the parameters which were significantly changed from 1989 to 1995 . In addition, the reduction in K-AL was tested against the $\mathrm{K}_{\mathrm{HNO}}$ concentration in 1989, and the increase in $\mathrm{K}_{\mathrm{HNO} 3}$ was tested against the K-AL concentration in 1989 . Results from the 87 sample points where both layers were sampled were used in the correlation analysis. The significant changes presented in Table 3 were also found when paired t-tests were carried out on this part of the samples.

In the following text, the concentrations in 1989 are abbreviated as P-AL89, K-AL89, and so on. The observed reductions in P-AL, K-AL and $\mathrm{pH}$ in the upper soil layer were positively correlated to P-AL89, K-AL89 and pH89, respectively (Table 4). In the subsoil, reductions in $\mathrm{K}-\mathrm{AL}$ and $\mathrm{pH}$ were positively correlated to K-AL89 and $\mathrm{pH} 89$, respectively (Table 5). In other words, the higher the P-AL, K-AL and $\mathrm{pH}$ levels were in 1989, the greater the probability for reductions six years later. This was most evident for $\mathrm{K}-\mathrm{AL}$ in the upper soil layer (Fig. 5). 


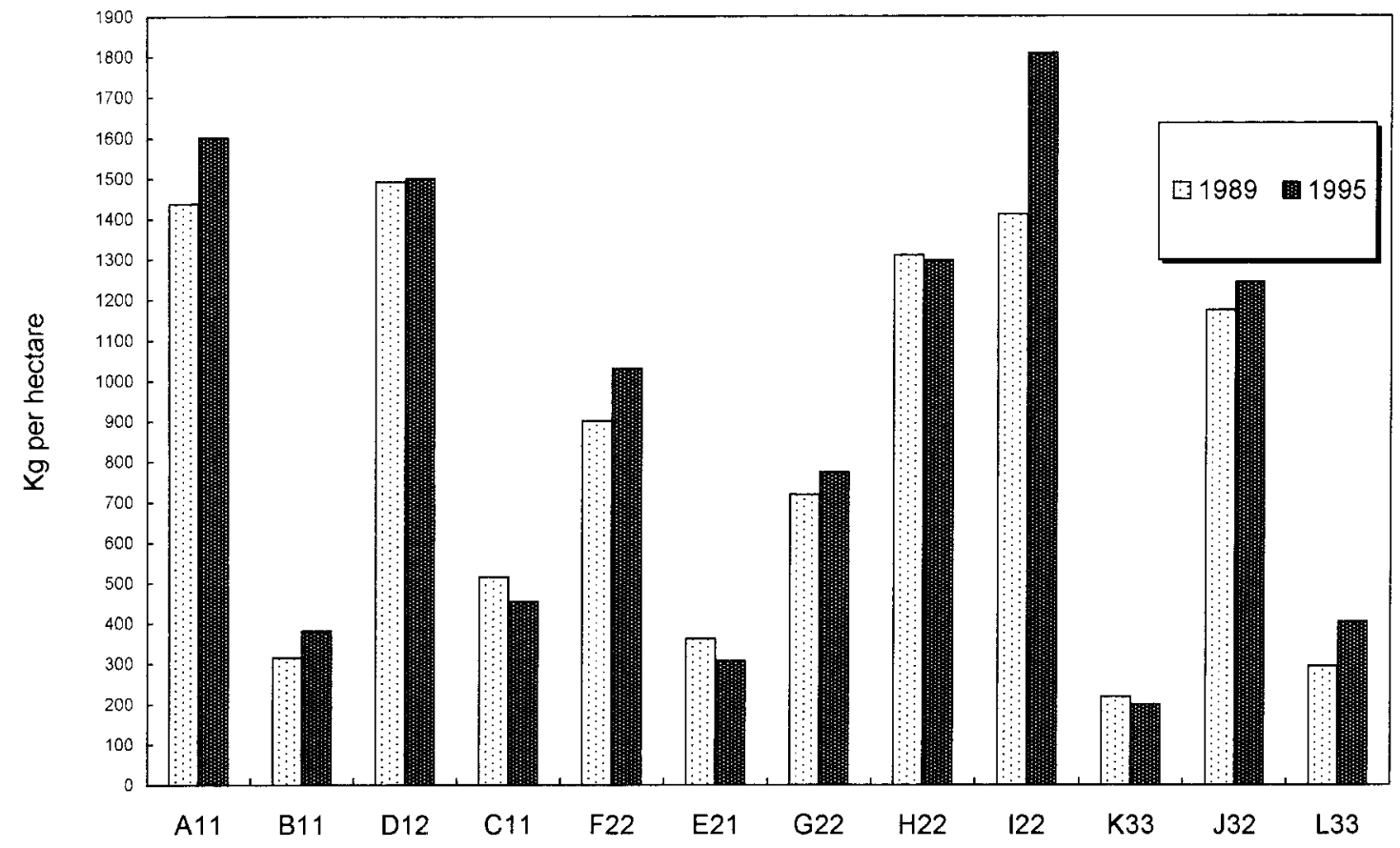

Fig. 4. $\mathrm{K}_{\mathrm{FINO}}$ reserves in the topsoil $\left(0-20 \mathrm{~cm}\right.$ ) on the 12 investigated farms (A11-L33) in 1989 comparcd to $1995, \mathrm{~kg} \mathrm{ha}^{-1}$.

The increase in $\mathrm{K}_{\mathrm{HNO}}$ in the topsoil was negatively correlated to $\mathrm{pH} 89$ and positively correlated to $\mathrm{K}$ AL89 and to the reduction in K-AL (not shown in Table $4, r=0.39^{* * *}$ ). The reduction in $\mathrm{K}-\mathrm{AL}$ was positively correlated to $\mathrm{K}_{\mathrm{HNO} 3} 89$ in the topsoil. In the subsoil, the reduction in K-AL was negatively correlated to the corrected clay content.

The reduction in $\mathrm{pH}$ was positively correlated to the corrected clay content in both layers. The reduction in $\mathrm{Mg}-\mathrm{AL}$ was positively correlated to the corrected clay content as well as $\mathrm{pH} 89$, and the increase in total- $\mathrm{N}$ was positively correlated to the subsoil $\mathrm{pH} 89$

For closer investigation of the relationship between nutrient concentration levels and changes from 1989 to 1995 , the soil samples from each layer were divided into classes based on P-AL and K-AL levels in 1989. and the changes in each class were determined by paired t-tests (Table 6). Statistically significant reductions were found in soil samples with high and very high concentrations of P-AL and K-AL in 1989. In soil samples with low concentrations of $\mathrm{K}-\mathrm{AL}$ in 1989, a significant increase was found. One topsoil sample only had a low P-AL concentration in 1989. A tendency toward increase in soil samples with a medium P-AL concentration was found $(P=0.055)$. Even if no significant change in the overall average P-AL concentration was found in the subsoil, splitting the samples into classes showed significant increases in the number of samples with low and medium P-AL concentrations in 1989, and reductions in samples with very high $\mathrm{P}-\mathrm{AL}$ concentrations.

As shown in Table 1 , the content of organic matter varied considerably in this material. Hence, the samples were grouped according to the content of total-C in 1989 , to determine whether the significant increase in total- $\mathrm{N}$ in the subsoil and possible significant changes in total- $\mathrm{N}$ and total- $\mathrm{C}$ in each class could be correlated to the content of organic matter in the soil. In both the topsoil $(n=19)$ and the subsoil $(n=48)$ significant increases in total- $\mathrm{N}$ and total-C were found using paired t-tests for samples with total-C $<1.7$ weight $\%$ in 1989 . The average total-C concentration in this class increased from 1.58 to $2.0 \%$ in the topsoil and from 0.98 to $1.34 \%$ in the subsoil. The average total- $\mathrm{N}$ concentration in this class increased from 0.12 to $0.17 \%$ in the topsoil, and from 0.08 to $0.11 \%$ in the subsoil. For total-N, a significant increase was found in yet another group of soil samples, namely $n=159$ topsoil samples containing $1.7-3.5$ weight $\%$ total-C in 1989 . On average, the total-N increased from $0.20 \%$ to $0.21 \%$ from 1989 to 1995 in this group, but this increase could be traced to the fertilizing practice on farm J32. The significant increases in total- $\mathrm{C}$ and total- $\mathrm{N}$ found for samples with $<1.7 \%$ total-C in 1989 could not be traced to the J32 fertilizing practice. For samples containing $>3.5 \%$ total-C in 1989 , no significant changes in total-C or total- $\mathrm{N}$ were found. 
Table 4. Correlation between reduction (diff.) in $\mathrm{pH}, \mathrm{P}-\mathrm{AL}$ and $\mathrm{K}-\mathrm{AL}$ and increase (diff.) in $\mathrm{K}_{\mathrm{HNO} 3}$ and the level of $\mathrm{pH}$, corrected clay content and concentrations of $\mathrm{P}-\mathrm{AL}, \mathrm{K}-\mathrm{AL}, \mathrm{K}_{\mathrm{HNO}}$, total- $\mathrm{N}$ and total-C in the topsoil $(0-20 \mathrm{~cm})$ in 1989. Pearson's correlation coefficient, $r$

\begin{tabular}{lllllll}
\hline Variable & pH89 & clay & P-AL89 & K-AL89 & K HNO3 $_{\text {-89 }}$ & Total-C89 \\
\hline Diff. $\mathrm{pH}$ & $0.45^{* * *}$ & $0.30^{* *}$ & & & $\mathrm{~ns}$ \\
Diff. P-AL & $\mathrm{ns}$ & $\mathrm{ns}$ & $0.45^{* * *}$ & & $\mathrm{~ns}$ & $\mathrm{~ns}$ \\
Diff. K-AL & $\mathrm{ns}$ & $\mathrm{ns}$ & & $0.69^{* * *}$ & $0.24^{*}$ & $\mathrm{~ns}$ \\
Diff. K- ${ }_{\text {HNO3 }}$ & $-0.33^{* *}$ & $\mathrm{~ns}$ & & $0.28^{* *}$ & $\mathrm{~ns}$ & \\
\hline
\end{tabular}

\section{Discussion}

\section{Changes in $P-A L$ and $K-A L$ concentrations}

Reductions in P-AL and K-AL concentrations were mostly found in soils with high concentrations of P-AL and/or K-AL in 1989 (Fig. 5, Tables 4, 5 and 6). Only 1 out of the 12 investigated farms had accomplished conversion in 1989. As shown by Kerner \& Solberg (1993), the net import of P and K is usually reduced during conversion from conventional to ecological milk production. Hence, the reduced P-AL and K-AL concentration from 1989 to 1995 in this material might be seen as a change towards a new level adapted to lower net imports of $\mathrm{P}$ and $\mathrm{K}$ on conversion to ecological farming. Further investigations are required to determine whether the average $\mathrm{P}-\mathrm{AL}$ and $\mathrm{K}-\mathrm{AL}$ concentrations will be further reduced, or if the concentrations measured in 1995 represent a "steady state"-level adapted to the new production system. In the long-term DOK-trial it was not possible after 14 years to conclude whether or not the concentrations of plant-available $\mathrm{P}$ and $\mathrm{K}$ had stabilized on a level determined by the production system. However, the changes occurred more slowly in the last seven years than in the first 7-year period (Alföldi et al., 1993).

\section{Relationship between net import and changes in reserves}

For $\mathrm{P}$, a correlation was found between net imports at farm level and changes in P-AL topsoil reserves. High net import of $\mathrm{P}$ gave a smaller reduction of the $\mathrm{P}-\mathrm{AL}$ reserve on the farm, or even increased the $\mathrm{P}-\mathrm{AL}$ reserve in some cases. A significant reduction in the average topsoil P-AL concentration on all farms with low net imports of $\mathrm{P}$ confirms this correlation, as well as a significant increase in topsoil P-AL. concentration on one of the three farms with a high level of net import of $\mathrm{P}$ (K33). A comparable relationship was described by Ekeberg \& Riley (1995), who found a strong positive correlation between Pbalances at field level and the P-AL concentration in the soil in a long-term fertilizer experiment at Møystad, Norway.
The lack of correlation between the net import of $\mathrm{K}$ at farm level and the reduction in the $\mathrm{K}-\mathrm{AL}$ reserve could be due to the fact that 12 farms were too few to find a correlation, or that the farm-level nutrient balances were too inaccurate. Farm-level nutrient balances have been criticized for being too inaccurate to estimate, for example, the risk of pollution from farming systems, because internal losses of nutrients are not shown (Askegaard \& Mikkelsen, 1995). This is more important for $K$ than for $P$, because $\mathrm{K}$ is in general a more mobile nutrient. $\mathrm{P}$ will not be leached from light soils as readily as $K$. Internal losses such as leaching of $\mathrm{K}$ from compost heaps and soil influence the relationship between the net import (export) of $\mathrm{K}$ and the $\mathrm{K}$-concentration in the soil. Hence, the actual K-export can be very different from the possible K-export calculated by farm-level nutrient balances. For instance, average net export of $\mathrm{K}$ was estimated to $36 \mathrm{~kg} \mathrm{ha}^{-1} \mathrm{yr}^{-1}$ at the field level on an organic farm in Germany (Mayer, 1997). At farm level the estimated net export was only $7 \mathrm{~kg} \mathrm{ha}^{-1} \mathrm{yr}^{-1}$.

Field-level nutrient balances are definitely more accurate than farm-level balances, but require measurements of yields, run-off, etc., which may limit the number of fields and farms in the investigation. A positive correlation between the total net exports of both $\mathrm{P}$ and $\mathrm{K}$ during 11 experimental years and the $\mathrm{K}-\mathrm{AL}$ and $\mathrm{P}-\mathrm{AL}$ concentrations on field level was found by Hansen (pers. comm.) in an organic dairy production system on silty sand soil.

\section{Influence of net import of $P$ versus $P-A L$ concentration in 1989 on the P-AL concentration in 1995}

Both the net import of $P$ to the farm and the level of P-AL concentration in the soil in 1989 influenced the topsoil P-AL concentrations in 1995. Significant reductions in the P-AL concentration might have been expected on all farms with high or very high average topsoil P-AL concentration in 1989, i.e. all farms with the exception of B11, F22 and J32. In fact, significant reductions occurred only on farms with low net imports of $\mathrm{P}(\mathrm{Al} 1, \mathrm{BI}, \mathrm{D} 12$ and $\mathrm{C} 11)$. The 
Table 5. Correlation between reduction (diff.) in $\mathrm{pH}, \mathrm{K}-\mathrm{AL}$ and $\mathrm{Mg}-\mathrm{AL}$ and increase (diff.) in tot- $\mathrm{N}$; and the level of $\mathrm{pH}$, corrected clay content and concentrations of $\mathrm{K}-\mathrm{AL}, \mathrm{Mg}-\mathrm{AL}, \mathrm{K}_{\mathrm{HNO}}$, tot- $\mathrm{N}$ and tot-C in the subsoil (20-40 $\mathrm{cm}$ ) in 1989. Pearson's correlation coefficient, $r$

\begin{tabular}{llllllll}
\hline Variable & $\mathrm{pH} 89$ & Clay & K-AL89 & Mg-AL89 & $\mathrm{K}_{\mathrm{HNO}}-89$ & Total-N89 & Total-C89 \\
\hline Diff. $\mathrm{pH}$ & $0.54^{* * *}$ & $0.37^{* * *}$ & & & $\mathrm{~ns}$ \\
Diff. K-AL & $\mathrm{ns}$ & $-0.23^{*}$ & $0.75^{* * *}$ & & $\mathrm{~ns}$ & $\mathrm{~ns}$ \\
Diff. Mg-AL & $0.37^{* *}$ & $0.36^{* * *}$ & & $0.64^{* * *}$ & & $\mathrm{~ns}$ \\
Diff. total-N & $0.23^{*}$ & $\mathrm{~ns}$ & & & $\mathrm{~ns}$ & $\mathrm{~ns}$ \\
\hline
\end{tabular}

only farm (K33) with a significant increase in the average topsoil P-AL concentration from 1989 to 1995 already had high average topsoil P-AL concentration in 1989. It appears that on the farms investigated in this study, the net imports of $\mathrm{P}$ had greater influence on the changes in the average topsoil P-AL concentrations than the P-AL level in 1989

\section{Relationship between changes in $K-A L$ concentration and some soil parameters}

The negative correlation between corrected clay content and the reduction in K-AL in the subsoil is as expected, because soil rich in clay usually has large reserves of potassium. In the topsoil, factors other than the clay content (e.g. addition of manure) have probably had a greater influence on the reduction of $\mathrm{K}-\mathrm{AL}$, and thus no correlation was found. Usually the root development in the topsoil is greater than in the subsoil, and it might be that plant-available $\mathrm{K}$ is removed faster than can be replaced by the clay minerals in this layer.

Larger average reduction in $\mathrm{K}-\mathrm{AL}$ than $\mathrm{P}-\mathrm{AL}$ concentrations could be caused by $\mathrm{K}-\mathrm{AL}$ being more unstable in the soil than P-AL and that more $\mathrm{K}$ than $\mathrm{P}$ is removed by crops. $\mathrm{K}$ is also more exposed to leaching. On farms $\mathrm{C} 11$ and $\mathrm{F} 22$ the $\mathrm{K}-\mathrm{AL}$ reserves in the topsoil were reduced to 50 and $75 \%$, respectively, of the original level in 1989. Above average rainfall (390 versus the normal $140 \mathrm{~mm}$ on C11, 214 versus the normal $119 \mathrm{~mm}$ on F22 in September 1995) prior to soil sampling in October might have influenced the K-AL concentrations on these farms. Semb (1966) investigated seasonal variations in the content of P-AL and K-AL in Norwegian agricultural soil and found larger variations of $K-A L$ between different seasons than of P-AL.

\section{Relationship between changes in $K_{\text {HNO3 }}$ concentration and some soil parameters}

The observed increase in $\mathrm{K}_{\mathrm{HNO}}$ in the topsoil was somewhat surprising, but was only significant when calculated as concentrations, not as reserves. The $\mathrm{K}_{\text {HNO3 }}$-fraction includes non-exchange- able $K$. One explanation for the $K_{1 \text { Nos }}$ increase could be that $\mathrm{K}^{+}$was fixed in the clay lattice because of reduced concentration of $\mathrm{NH}_{4}^{-}$ions in the soil solution due to a gradual decrease in the use of inorganic fertilizer at the investigated farms in this time period. $\mathrm{NH}_{4}^{+}$may, in the same way as $\mathrm{K}^{-}$, be fixed on non-exchangeable positions within the clay lattice. With reduced $\mathrm{NH}_{4}^{+}$concentration in the soil solution, non-exchangeable $\mathrm{NH}_{4}^{+}$may be replaced by $\mathrm{K}^{-}$. Several authors have shown that the $\mathrm{NH}_{4}^{+}$to $\mathrm{K}^{+}$ratio influences the fixing of $\mathrm{K}^{+}$. Chen \& Mackenzie (1992) found reduced fixing of $\mathrm{K}^{+}$when increasing dressings of $\mathrm{NH}_{4}^{+}$were applied to Canadian soils with relatively high fixing capacities for both $\mathrm{K}^{-}$and $\mathrm{NH}_{4}^{+}$. Garz et al. (1993) found increasing fixing capacity of $\mathrm{K}^{+}$in soils according to the degree of $\mathrm{K}$ depletion in German soil, and found that fixing of $\mathrm{NH}_{4}^{+}$was dependent on the $\mathrm{K}$-depletion as well. Hence, a fixing of $\mathrm{K}^{+}$caused by depletion of $\mathrm{NH}_{4}^{+}$may be one explanation for the increased $\mathrm{K}_{\mathrm{HNO} 3}$ concentration in the present study.

The increase in $\mathrm{K}_{\mathrm{HNO}}$ was positively correlated to the concentration of K-AL in the topsoil in 1989 and to the reduction in $\mathrm{K}-\mathrm{AL}$ in the topsoil from 1989 to 1995 , indicating that $\mathrm{K}_{\mathrm{HNO}}$ increased most in soils rich in $\mathrm{K}-\mathrm{AL}$, and that some $\mathrm{K}-\mathrm{AL}$ was fixed in the topsoil. But as the increase in $\mathrm{K}_{\mathrm{HNO}}$ concentrations was in general much larger than the reduction in $\mathrm{K}-\mathrm{AL}$ concentrations, the increase in $\mathrm{K}_{\mathrm{HNO} 3}$ cannot solely be explained by a corresponding reduction in $\mathrm{K}-\mathrm{AL}$. Fixing of $\mathrm{K}^{+}$added in manure and/or released by weathering has probably contributed to the observed increase in $\mathrm{K}_{\mathrm{HNO3}}$. The increase in $\mathrm{K}_{\mathrm{HNO3}}$ was negatively correlated to $\mathrm{pH} 89$. Increased weathering with decreasing $\mathrm{pH}$ may be an explanation

\section{Relationship between changes in Mg-AL concentration and some soil parameters}

A significant reduction in the overall average $\mathrm{Mg}-\mathrm{AL}$ concentration, twice as large as the reduction in $\mathrm{K}-\mathrm{AL}$, was found in the subsoil. A significant decrease in the $\mathrm{Mg}-\mathrm{AL}$ concentration was found in both soil layers, on several farms. The reduction in $\mathrm{Mg}-\mathrm{AL}$ was positively correlated to the $\mathrm{Mg}-\mathrm{AL}$ concentration 




Fig. 5. Changes in the K-AL concentration in the topsoil $(0.20 \mathrm{~cm})$ from 1989 to 1995 as a function of K-AL concentrations in 1989 (mg $\mathrm{K}$ per $100 \mathrm{~g}$ dry soil). Positive values = increase, negative values = decrease from 1989 to 1995.

in 1989 , to the pH-level in 1989 and to the corrected clay content. The larger reduction in samples with high concentrations of Mg-AL in 1989 is the same trend as found for K-AL and P-AL. Less reduction of $\mathrm{Mg}-\mathrm{AL}$ in soil with low clay content is surprising because clay soils usually have larger reserves of $\mathrm{Mg}$ than sandy soils. No valid explanation was found for the correlation between the reduction in $\mathrm{Mg}-\mathrm{AL}$ from 1989 to 1995 and the level of $\mathrm{pH}$ in 1989.

In the DOK trial a close relationship was found between the $\mathrm{Mg}$ balance at field level and the concentration of plant-available $\mathrm{Mg}$ in the soil (Alföldi et al., 1993). In the present study, no nutrient balances were calculated for $\mathrm{Mg}$, but in general the net imports of nutrients to these farms decreased during the conversion period.

\section{Changes in total- $N$ and organic matter (total-C) from 1989 to 1995}

In the subsoil, a positive correlation was found between the increase in total-N from 1989 to 1995 and the level of $\mathrm{pH}$ in 1989. However, this correlation disappeared when four samples containing $>12 \%$ total-C in 1989 were excluded from the correlation analysis. The reason for excluding these samples was a Norwegian definition by Sveistrup (1984) which states that soils containing $<12 \%$ total-C are called mineral soils. In other words, in mineral subsoil samples no correlation was found between the increase in total-N and the level of $\mathrm{pH}$ in 1989.

When the soil samples were classified according to their content of total-C in 1989, significant increases were found in the total- $\mathrm{N}$ and total- $\mathrm{C}$ concentrations in both top- and subsoil containing $<1.7$ weight $\%$ total-C in 1989. This indicates that in soil with a low organic-matter content, organic dairy farming may increase the content of total-C. A comparable increase in the content of soil organic matter was found in a Swedish long-term experiment comparing different organic amendments to the soil (Persson \& Kirchmann, 1994). In 1956, the clay soil contained $1.49 \%$ total-C and $0.17 \%$ total-N. After 35 years with an addition of approximately 40 tons solid cattle manure ha- ${ }^{-1}$ every 2 nd year in autumn, the total-C concentration had increased to $2.10 \%$, and was not yet stabilized. The fertilizing was somewhat higher than average amounts used in Norwegian ecological dairy farming, where approximately 9-14 tons of farmyard manure are available per hectare and year (Fritsvold et al., 1996).

In the DOK experiment the original content of organic matter in the soil was $1.7 \%$, which is comparable with these results. But only small, if any, changes in the content of organic matter were found (Alföldi et al., 1993). A cool climate and a heavy 


\section{A.-K. Loes and A. F. Ogaard}

Table 6. Average change in the P-AL and K-AL concentrations in different nutrient classes (1-4), in the topsoil $(0-20 \mathrm{~cm})$ and subsoil $(20-40 \mathrm{~cm}) ; \mathrm{mg} P$ or $\mathrm{K}$ per $100 \mathrm{~g}$ dry soil. The classification is based on the concentration of the respective nutrients in the 1989 samples. Changes are defined as level in 1995 minus level in 1989; positive values indicate an increase, negative values a reduction in nutrient concentration; $n=$ number of samples in the respective class

\begin{tabular}{lcccc}
\hline $\begin{array}{l}\text { Class: } \\
\text { Concentration: }\end{array}$ & 1 & 2 & 3 & 4 \\
& Low & Medium & High & Very high \\
\hline P-AL, $0-20 \mathrm{~cm}$ & - & $0.46 \mathrm{~ns}$ & $-0.43^{*}$ & $-1.56^{* *}$ \\
$n$ & 1 & 89 & 132 & 88 \\
$\mathrm{P}-\mathrm{AL}, 20-40 \mathrm{~cm}$ & $0.7^{* * *}$ & $1.9^{* *}$ & $-0.6 \mathrm{~ns}$ & $-6.4^{* *}$ \\
$n$ & 25 & 33 & 18 & 11 \\
$\mathrm{~K}-\mathrm{AL}, 0-20 \mathrm{~cm}$ & $1.4^{* *}$ & $0.2 \mathrm{~ns}$ & $-6.4^{* * *}$ & $-16.6^{* * *}$ \\
$n$ & 69 & 127 & 101 & 13 \\
$\mathrm{~K}-\mathrm{AL}, 20-40 \mathrm{~cm}$ & $1.0^{* * *}$ & $-0.8 \mathrm{~ns}$ & $-11.2^{* * *}$ & - \\
$n$ & 38 & 39 & 9 & 1 \\
\hline
\end{tabular}

annual precipitation enhance the accumulation of organic matter in the soil. Hence, Swedish and Norwegian climatic conditions are conducive to increases in total-C compared to the conditions found in Switzerland, and this may explain the different results.

\section{Changes in pH from 1989 to 1995}

It is surprising that the reduction in $\mathrm{pH}$ was positively correlated to the corrected clay content in 1989 (both layers), because soil rich in clay usually has better buffering capacity than sandy and organic soils.

The $\mathrm{pH}$ reduction in this investigation is somewhat surprising, because organic farming does not suffer the acidifying effects of $\mathrm{NH}_{4}^{+}$fertilizers (ammonia). Acid precipitation contributes to reduced $\mathrm{pH}$ in soil. In Norway, the deposits of the main acidifying agents, sulphate $\left(\mathrm{SO}_{4}^{-}\right)$and nitrate $\left(\mathrm{NO}_{3}^{-}\right)$varied in 1988-92 from $17 \mathrm{~kg} \mathrm{~S}$ and $25 \mathrm{~kg} \mathrm{~N} \mathrm{ha}^{-1} \mathrm{yr}^{-1}$ along the southwest coast where the annual rainfall is very high, to $4 \mathrm{~kg} \mathrm{~S}$ and $<1 \mathrm{~kg} \mathrm{~N} \mathrm{Na}^{-1} \mathrm{yr}^{-1}$ in northern Norway where the rainfall is less and the precipitation is less polluted. In the past 15 years, significant reductions $(>30 \%)$ in the $\mathrm{S}$ concentrations in both air and precipitation have been measured, but the $\mathrm{N}$ concentrations remain high (Tørseth \& Semb, 1995). Organic farming makes extensive use of legumes fixing $\mathrm{N}_{2}$ from the atmosphere. $\mathrm{N}_{2}$-fixation involves excess uptake of nutrient cations over anions with a consequent net flux of $\mathrm{H}_{3} \mathrm{O}^{+}$ions from the plant root, thus contributing to soil acidification (Haynes, 1983). The general reduction in $\mathrm{pH}$ in this investigation indicates that even though organic farming does not reduce soil $\mathrm{pH}$ by adding ammonia as fertilizer, other processes may reduce $\mathrm{pH}$, making it necessary to observe the change in the soil $\mathrm{pH}$ and lime as required.

\section{Nutrient concentrations in topsoil compared to subsoil}

In general, the subsoil nutrient concentrations in this investigation were rather high. The average content of acid-soluble potassium was higher in the subsoil than in the topsoil. The average $\mathrm{pH}$-value and content of $\mathrm{Mg}-\mathrm{AL}$ were the same in both layers. The average contents of P-AL, K-AL, Ca-AL, total-N and organic matter were larger in the topsoil. Changes in the average concentrations of different parameters on each farm occurred more often in the topsoil than in the subsoil. The topsoil is more influenced by fertilizing, cultivation and uptake of nutrients than the subsoil. Hence, a smaller change in the nutrient concentrations from 1989 to 1995 in the subsoil compared to the topsoil was a result that could be expected.

\section{Diminishing plant-available nutrients?}

In this study, we found significant decreases in P-AL and $\mathrm{K}-\mathrm{AL}$ concentrations, but an increase in $\mathrm{K}_{\mathrm{HNO} 3}$, in the soil during conversion to organic agriculture on 12 Norwegian farms. We could not explain the increase in $\mathrm{K}_{\mathrm{HNO} 3}$ solely by a reduction in $\mathrm{K}-\mathrm{AL}$; the relationship was more complex. Complicated dynamics exist, both between different fractions of nutrients in the soil, and between nutrient fractions and other conditions such as climate, soil type and fertilizing. The P-AL, K-AL and Mg-AL concentrations are only expressions for a smaller part of the total content of nutrients in the soil, but the observed reductions in the average $\mathrm{K}-\mathrm{AL}$ and P-AL concentrations should be taken seriously. Excess rainfall might have contributed to large losses of K-AL on farm C11 and F22, but other farms experienced significant $\mathrm{K}-\mathrm{AL}$ reductions without excessive rainfall. The present study showed that reduced net P-import will, over 
time, give reduced concentrations of P-AL in the soil. For K-AL the relationship was not as clear, but agricultural production with net export at the field level of any mineral nutrient will reduce the total content of this nutrient in the soil. Even if the farms in the present study had a net import of $K$. there might have been net export of $K$ at the field level because of drainage losses, etc.

Some agricultural soils have large reserves of plant nutrients, and a sustainable farming practice may include techniques to promote a controlled release of plant-available nutrients from these sources. Other soils have only small reserves, and it may be necessary to import some nutrients from outside the farm, for instance compost from household wastes, stone meal or certain mineral fertilizers.

\section{Conclusions}

Significant changes were found in the concentrations of important soil nutrients and pH from 1989 to 1995 on farms in the process of conversion to organic agriculture. A significant reduction in the K-AL concentration and $\mathrm{pH}$ occurred in both top- and subsoil. A significant reduction in the P-AL concentration occurred in the topsoil only and a significant reduction in the $\mathrm{Mg}-\mathrm{AL}$ concentration only in the subsoil. $\mathrm{K}_{\mathrm{HNO}}$ was significantly increased in the topsoil, and total-N in the subsoil.

Reduction in K-AL and P-AL occurred in soils with high or very high initial concentrations, whereas increase occurred in soils with medium or low concentrations of K-AL and/or P-AL in 1989. Significant increases in total-C and total-N concentrations were found in soils with $<1.7 \%$ total-C in 1989 , showing that soils with a low content of organic matter can be enriched by organic farming. The average reduction in $\mathrm{pH}$ shows that even though organic farming does not acidify the soil by adding inorganic nitrogen fertilizer, other factors acidify the soil and the farmer should be aware of the situation and lime as necessary.

The reduction in $\mathrm{P}-\mathrm{AL}$ was negatively correlated to the net import of $P$ to the farms (sum of six years) calculated at the farm level. The average reduction in $\mathrm{K}$-AL was larger, but not correlated to the net import of $\mathrm{K}$. Nutrient balances at farm level proved to be accurate enough to reveal an expected correlation for $\mathrm{P}$, but not for $\mathrm{K}$. Internal losses of $\mathrm{K}$ on the farms are probably larger than internal losses of $P$.

An important aim of ecological farming is to promote the capacity of the soil to deliver the nutrients the crops demand. By net export of nutrients at the field level, restricted import of nutrients such as stone meal, household wastes, compost or certain mineral fertilizers may be necessary on farms with low concentrations of important plant nutrients in the soil.

\section{References}

Alföldi, T., Mäder. P.. Oberson. A.. Spiess, E., Niggli. U. \& Besson. J. M. 1993. DOK-Versuch: Vergleichende Langzeitsuntersuchungen in den drei Anbausystemen biologisch-dynamisch. organisch-biologisch und konventionell. III Boden: Chemische Untersuchungen. 1. und 2. Fruchtfolgeperiode. Schweiz. Landw. Fo. 32, pp. $479-507$.

Askegaard, M. \& Mikkelsen, G. 1995. Nieringsstofbalancer på bedriftsniveau i økologisk jordbrug. In: G. Olesen, J. E. \& Vester, J. (eds.). Naringsstofbalancer og energiforbrug i okologisk jordbrug. Fokus på kvægbedrifter og planteavl. Landbruks- og fiskeriministeriet, Statens plantcavlsforsøg. Rapport 9 , pp. $75-83$.

Bondorf, K. A. 1950. Om bestemmelse af jordens rumvagt. Tidsskr. Planteavl. 53, 450560.

Chen, J. S. \& Mackenzie, A. F. 1992. Fixed ammonium and potassium as affected by added nitrogen and potassium in 3 Quebec soils. Communications in Soil Science and Plant Analysis 23(11 12), 1145-1159.

Debio (Norwegian Certification Body), 1997a. Registreringer 1996. Merkegodkjenninger, arealer, produksjoner osv. Bjørkelangen, $62 \mathrm{pp}$.

Debio (Norwegian Certification Body), 1997b. Økologisk landbruk. Debioregler. Okologisk landbruksproduksjon. Bjørkelangen, 34 pp.

Ebbesvik, M., 1997. Nøkkeltall fra 13 gårder med økologisk drift. Resultater og kommentarer. Norsk senter for okologisk landbruk, Tingvoll, $196 \mathrm{pp}$.

Égner, H., Richm, H. \& Domingo, W. R. 1960. Untersuchungen über die chemische Boden-Analyse als Grundlage für die Beurteilung des Nährstoffzustandes der Boden. Kungl. Lantbrukshögskolans annaler 26, pp. 199215.

Ekeberg, E. \& Riley, H. 1995. The long-term fertilizer trials at Møystad, S.E. Norway. In: Christensen, B. T. \& Trentemølle, U. (eds.). The Askov Long term Experiments on Animal Manure and Mineral Fertilizer. 100th anniversary workshop. SP-report 29. pp. $83-97$

Elonen, P. 1971. Particle-size analysis of soil. Acta Agric. Fenn. 122, $1-122$.

Fritsvold, B., Løes, A. K. \& Schmidt, K. 1996. Omlegging til økologisk landbruk. 2. utgave. Landbruksforlaget, Oslo, $310 \mathrm{pp}$.

Garz. J.. Scharf, H., Stuumpe. H., Scherer, H. W. \& Schliephake, W. 1993. Effect of potassium fertilization on some chemical soil properties in a long-term trial on sandy loess. Potash-Review. 12ste, $1: 3,12 \mathrm{pp}$.

Hansen, S. 1997. Effekt av kjørebelastning og gjødsling på avling, jord og naringsforsyning, i næringsfattig og pakkingsutsatt jord. In Eltun, R. \& Serikstad, G. L. (eds.): Injormas jonsmati i cckologisk landbruk. Resultaten fra Norges Jorskningsråds Jorsk-ningsprogram 1992 -1996. Forskningsutvralget for $\emptyset$ kologisk landbruk, Norsk senter for $\emptyset$ kologisk landbruk. Tingvoll pp. $55-60$

Haynes, R. J. 1983. Soil acidification induced by leguminous crops. Grass and Forage Science 38, 1-11.

IFOAM (International Federation of Organic Agricultural Movements) 1994: Basic Standards for Organic Agriculture and Food Processing decided by the IFOAM General Assembly at Christchurch New Zealand, December 15th 1994.

Kerner, K. \& Solberg, S. Ø. 1993. Neringshusholdning i økologisk landbruk. Del 1: Handelsbalanser for nitrogen, fosfor og kalium pả gårdene i 30 bruks-prosjektet. Faginfo $\mathrm{nr} 20$ fra Statens fagtjeneste for landbruket. Ảs, pp. 13-32. 


\section{A.-K. Loes and A. F. Ogaard}

Kristensen, I. S. \& Halberg. N. 1995. Markens nettoudbytte. naringsstofforsyning og afgrodetilstand pä okologiske og konventionelle kvagbrug. In: Kristensen, E. S. (ed.). Okologisk landbruk med udgangspunkt i kvegbedriften. Bilag til seminar afholdt i Herning Kongreseenter. Landbruksministeriet. Statens Husdyrbrugsforsøg, Intern rapport 42. pp. 3351.

Mayer, J. 1997: Ist die Kaliumversorgung ausreichend und gesichert? Ökologie und Landbau 101, $30-33$

Olsen, R. S., Cole, C. V., Watanabe, F. S. \& Dean, L.-A. 1954 Estimation of available phosphorus in soils by extraction with sodium bicarbonate. US Dept. Agric. Circ. No. 939

Persson, J. \& Kirchmann. H. 1994. Carbon and nitrogen in arable soils as affected by supply of $\mathrm{N}$ fertilizers and organic manures. Agriculture, Ecosystems and Environment 51, 249-255.

Pettersson, B. D., Reents H. J. \& Wistinghausen E. V. 1992 Düngung und Bodeneigenschaften. Ergebnisse eines 32-jährigen
Feldversuches in Järna, Schweden. Nordisk Forskningsring. Meddelande 34. Järna, $59 \mathrm{pp}$.

Scheffer, F. \& Schachtschabel, P. 1982: Lehrbuch der Bodenkunde. 11., neu bearbeitete Auflage. Ferd. Enke Verlag. Stuttgart.

Semb, G. 1966. Arstidsvariasjoner i jordas innhold av lettopploselig fosfor, kalium og magnesium. Forskning og forsok i landbruket, Jordundersokelsens sertrykk ni 114, pp. 165193.

Sveistrup, T. 1984. Retningslinjer for beskrivelse av jordprofil. Jord og myr 2(8). 3077.

Sveistrup, T. \& Njøs, A. 1984. Kornstorrelsesgrupper i mineraljord. Revidert forslag til klassifisering. Jord og myr 8, 8 15.

Torseth, K. \& Semb, A. 1995. Sulphur and nitrogen deposition in Norway, status and trends. Water, Air and Soil Pollution 85. $623-628$. 